Gut, 1973, 14, 519-528

\title{
Effects on small-intestinal function and structure induced by feeding a deconjugated bile salt
}

\author{
MICHAEL GRACEY, JOHN PAPADIMITRIOU, VALERIE BURKE, ${ }^{2}$ JENNIFER \\ THOMAS, AND GEOFFREY BOWER \\ From the Gastroenterological Research Unit, Princess Margaret Children's Medical Research Foundation, \\ and the Department of Pathology, School of Medicine, University of Western Australia, Perth, Western \\ Australia
}

SUMMARY Feeding sodium deoxycholate orally to rats for three days caused inhibition of smallintestinal active sugar transport and ouabain-sensitive, sodium-potassium-dependent adenosine triphosphatase activity. At the same time, there was evidence of extensive ultrastructural damage to the microvillar and intracellular compartments of the small-intestinal epithelium while its light microscopic appearance was essentially normal. These functional and morphological changes reverted towards normal over the subsequent four days when a normal diet, without added bile salt, was reintroduced.

Chromatographically pure deconjugated bile salts inhibit intestinal sugar transport in vivo by an incompletely understood mechanism (Gracey, Burke, and Oshin, 1971a; Harries and Sladen, 1972). This seems pertinent to the production of diarrhoea in patients with bacterial overgrowth in the upper intestine, particularly in infancy, where monosaccharide malabsorption may be the major clinical problem in this situation (Gracey, Burke, Oshin, Barker, and Glasgow, 1971c). We report here a convenient experimental model in which the relationship of bile salts to intestinal sugar transport can be investigated in vitro or in the intact animal in vivo.

\section{Materials and Methods}

ANIMALS AND FEEDING PROCEDURE

Adult Wistar rats weighing 150-250 g were used throughout. They were bred from a long-established, closed colony in the University of Western Australia. Experimental animals each had $25 \mathrm{mg}$ of chromatographically pure sodium deoxycholate ${ }^{3}$ added daily for 72 hours to the standard laboratory diet by sprinkling the bile salt powder over water-sodden feed cubes. After the feeding period, a normal diet, without added bile salt, was recommenced. Intestinal

${ }^{1}$ Adolph Basser research fellow of the Royal Australasian College of Physicians

'Supported by a part-time research grant of the Royal Australasian College of Physicians

'Maybridge Chemical Company, Cornwall.

Received for publication 12 April 1973 sugar absorption was studied in vitro and in vivo at daily intervals for up to four days from the completion of the feeding period; simultaneously, small-intestinal ouabain-sensitive, sodium-potassium-dependent adenosine triphosphatase $\left(\mathrm{Na}^{+}+\right.$ $\mathrm{K}^{+}$ATPase) activity was examined chemically and histochemically. Light and electron microscopy of the small intestine was also studied at these time intervals.

\section{UPTAKE STUDIES in vitro}

The uptake studies in vitro were done using the method described by Semenza and Mulhaupt (1969). This technique measures the uptake of substrate by pieces of tissue mounted in a plexiglass tissue-holding apparatus. The animals were killed in a jar saturated with anaesthetic ether. The abdominal cavity was then opened, the small intestine removed and washed through with Krebs-Henseleit (1932) bicarbonate buffer at $37^{\circ} \mathrm{C}$ and $\mathrm{pH} 7 \cdot 4$. The gut was then everted and segments $1.5 \mathrm{~cm}$ long not containing Peyer's patches were mounted in a plexiglass tissue-holding apparatus. The substrate chosen was arbutin (p-hydroxyphenyl- $\beta$-glucoside); this is a synthetic analogue of D-glucose and is transported by the small intestine of the rat by the same mechanism as glucose (Alvarado and Crane, 1964). It has the advantage over glucose of not being metabolized by the small-intestinal epithelium and is a recognized material for investigation of the intestinal

¿Sigma Chemical Company. 
active sugar transport pathway (Gracey et al, 1971a).

The incubation medium was based on KrebsHenseleit (1932) bicarbonate buffer, at $37^{\circ} \mathrm{C}$ and pH $7 \cdot 4$, to which was added $5 \mathrm{mM}$ arbutin; $3 \mathrm{mM}$ 2-deoxy-D-glucose ${ }^{4}$ was included in the medium to assess the amount of sugar entering the tissue by passive diffusion (Bihler and Crane, 1962); this index was subtracted from the arbutin uptake figures. The medium was pregassed for 60 minutes immediately before and throughout the experiments with $95 \% \mathrm{O}_{2}$ and $5 \% \mathrm{CO}_{2}$.

\section{ABSORPTION STUDIES in vivo}

The substrate used was based on Krebs-Henseleit (1932) bicarbonate buffer to which was added $10 \mathrm{mM}$ arbutin with $2 \mathrm{mg} / \mathrm{ml}$ of polyethylene glycol $4000^{1}$ included as a non-absorbable marker. This solution, at $37^{\circ} \mathrm{C}$ and $\mathrm{pH} 7.4$, was pregassed with $95 \% \mathrm{O}_{2}$ and $5 \% \mathrm{CO}_{2}$ for 60 minutes immediately before the experiments.

The animals were lightly anaesthetized with open ether and the abdomen opened with a mid-line incision. Two $\mathrm{ml}$ of the solution was introduced into a $20 \mathrm{~cm}$ segment of mid-jejunum which was then returned to the abdominal cavity and the abdominal wound closed with metal clamps. After 10 minutes, the segment was removed and its contents collected. The animals were killed by incising the heart.

\section{ANALYTICAL METHODS}

Arbutin was determined as free phenol (Folin and Ciocalteu, 1927; Lowry, Rosebrough, Farr, and Randall, 1951); polyethylene glycol by a micromodification of Hydén's method (1956); 2 deoxy-Dglucose was determined by the formation of malonic dialdehyde with periodate and on its condensation with barbituric acid (Waravdekar and Saslaw, 1957). $\left(\mathrm{Na}^{+}+\mathrm{K}^{+}\right)$ATPase activities of tissues taken immediately before the uptake studies in vitro were assayed by a micro-modification of Hirschorn and Rosenberg's (1968) procedure.

Uptake of arbutin in vitro is expressed as tissue concentration in $\mu$ moles $/ \mathrm{ml}$ of tissue water after correction for passive diffusion indicated by the degree of entry of 2 deoxy-D-glucose while assuming a tissue water content of $80 \%$ (Crane and Mandelstam, 1960). The rate of absorption of arbutin in vivo is expressed as $\mu$ moles of substrate per $\mathrm{cm}$ of intestine per hour as measured by its disappearance from the lumen, after appropriate adjustment for changes in volume indicated by differences between polyethylene glycol concentrations before and after the experiments.

Standard mathematical methods were used to ${ }^{1}$ British Drug Houses calculate means and standard deviations (SD). Levels of statistical significance were obtained by means of Student's $t$ test; $P$ values of $<0.05$ are taken to be significant.

\section{HISTOCHEMISTRY}

The ouabain-sensitive, sodium-potassium-dependent adenosine triphosphatase activity in control and experimental specimens was localized using the cytochemical technique of Ernst (1972). All specimens were maintained at $-70^{\circ} \mathrm{C}$ then sectioned and placed in the same incubation medium, thus allowing direct comparison of the various specimens.

\section{LIGHT AND ELECTRON MICROSCOPY}

Specimens for light microscopy were fixed in formolsaline and carefully orientated before mounting and staining with haematoxylin and eosin.

For electron microscopy, specimens were fixed in $3 \%$ glutaraldehyde in $0 \cdot 1 \mathrm{M}$ cacodylate buffer for 16 hours at pH 7.4. After washing in buffer, the tissues were postfixed in $1 \%$ osmium tetroxide in $0.1 \mathrm{M}$ cacodylate buffer, at pH $7 \cdot 4$, for one hour. They were then dehydrated in graded solutions of ethanol and embedded in araldite. Sections were cut on an LKB ultramicrotome, stained with lead hydroxide, and examined on a JEM T6 or a Philips 300 electron microscope.

\section{Results}

SUGAR UPTAKE in vitro (SEE TABLE I)

With $5 \mathrm{mM}$ as substrate, the mean uptake in normal animals ranged from $5.8 \mu$ moles $/ \mathrm{ml}$ tissue water at 10 minutes' incubation to $7.5 \mu \mathrm{moles} / \mathrm{ml}$ tissue water at $\mathbf{4 0}$ minutes. At the completion of the threeday bile salt feeding period the rate of uptake was significantly impaired throughout the incubation period. This effect persisted for 72 hours. Results at that time were $3.3( \pm 1 \mathrm{SD}, 1.4)$ at 10 minutes to $5.3( \pm 1 \mathrm{SD}, 0.8)$ at 40 minutes. However, after resumption of a normal diet for 96 hours, there was some recovery; after incubation for 30 and 40 minutes the results were $6.9( \pm 1 \mathrm{SD}, 1 \cdot 1)$ and $7 \cdot 3$ $( \pm 1 \mathrm{SD}, 2 \cdot 7)$ respectively These results were not significantly different from control values

SUGAR ABSORPTION in vivo (SEE TABLE II)

Under control conditions the rate of absorption of arbutin was $3.17 \mu$ moles per cm intestine per hour $( \pm 1 \mathrm{SD}, 1.02)$. Immediately after the bile salt feeding period this was significantly depressed (1.86; \pm SS, 0.9$)$ and remained so for 48 hours $(2.07$, \pm 1SD, 0.75). By 72 hours after the feeding period the rate of absorption of arbutin had returned to within normal limits $(2 \cdot 99 ; \pm 1 S D, 0 \cdot 87)$. 


\begin{tabular}{|c|c|c|c|c|c|c|}
\hline \multirow{2}{*}{$\begin{array}{l}\text { Incubation } \\
\text { Time (mins) }\end{array}$} & \multirow[t]{2}{*}{ Normal Rats } & \multicolumn{5}{|c|}{ Hours after Bile Salt Feeding Period } \\
\hline & & 0 & 24 & 48 & 72 & 96 \\
\hline $\begin{array}{l}10 \\
20 \\
30 \\
40\end{array}$ & $\begin{array}{l}5.8 \pm 0.9(13) \\
6.5 \pm 1.1(25) \\
7.0 \pm 1.3(26) \\
7.5 \pm 1.9(27)\end{array}$ & $\begin{array}{l}3.6 \pm 0.7^{2}(17) \\
4.5 \pm 0.6^{2}(16) \\
5.6 \pm 1.3^{2}(18) \\
5.6 \pm 1.1^{2}(16)\end{array}$ & $\begin{array}{l}3.5 \pm 0.7^{2}(18) \\
4.7 \pm 0.9^{2}(18) \\
4.7 \pm 1.3^{2}(18) \\
4.9 \pm 1.4^{2}(17)\end{array}$ & $\begin{array}{l}3.8 \pm 1.0^{2}(18) \\
4 \cdot 1 \pm 1.0^{2}(21) \\
4.9 \pm 0.9^{2}(17) \\
4.6 \pm 1.2^{2}(17)\end{array}$ & $\begin{array}{l}3.3 \pm 1.4^{2}(5) \\
4.4 \pm 0.7^{2}(5) \\
5.5 \pm 0.5^{2}(5) \\
5.3 \pm 0.8^{2}(5)\end{array}$ & $\begin{array}{l}3 \cdot 8 \pm 0 \cdot 8^{\mathrm{s}}(6) \\
5 \cdot 0 \pm 1 \cdot 5^{3}(6) \\
6 \cdot 9 \pm 1 \cdot 1^{\mathrm{ns}}(6) \\
7 \cdot 3 \pm 2 \cdot 7^{\mathrm{ns}}(6)\end{array}$ \\
\hline
\end{tabular}

Table I Arbutin uptake in vitro by normal rat small intestine and following a three-day period of feeding deoxycholate $^{1}$

${ }^{1}$ Incubations were performed in a medium containing $5 \mathrm{mM}$ arbutin. Results are expressed as $\mu$ moles of arbutin/ml of tissue water. Figures in parentheses indicate the number of observations.

Indicates $P<0.001$

Indicates $P<0.01$

ns indicates no statistical significance.

\begin{tabular}{|c|c|c|c|c|c|}
\hline \multirow[t]{2}{*}{ Normal Rats } & & \multicolumn{4}{|c|}{ Hours after Bile Salt Feeding Period } \\
\hline & & 0 & 24 & 48 & 72 \\
\hline $\begin{array}{l}\text { Number } \\
\mathbf{P}\end{array}$ & $\begin{array}{l}3.17 \pm 1.02 \\
11\end{array}$ & $\begin{array}{l}1.86 \pm 0.90 \\
8 \\
<0.005\end{array}$ & $\begin{array}{l}2.04 \pm 0.88 \\
7 \\
<0.01\end{array}$ & $\begin{array}{l}2.07 \pm 0.75 \\
10 \\
<0.01\end{array}$ & $\begin{array}{l}2.99 \pm 0.87 \\
10 \\
0.3<P<0.35\end{array}$ \\
\hline
\end{tabular}

Table II Arbutin absorption from a solution containing $10 \mathrm{mM}$ arbutin in vivo by normal rat small intestine and following three-day period of feeding deoxycholate

${ }^{1}$ Results indicate $\mu$ moles of substrate absorbed per $\mathrm{cm}$ intestine per hour.

\begin{tabular}{llllll}
\hline & Normal Rats & \multicolumn{4}{l}{ Hours after Bile Salt Feeding Period } \\
\cline { 2 - 5 } & & 0 & 24 & 48 & 72 \\
\hline Number & $88 \pm 25$ & $17 \pm 8$ & $35 \pm 21$ & $62 \pm 19$ & $74 \pm 18$ \\
$\mathbf{P}$ & 15 & -60.001 & 6 & 6 & 6 \\
\hline
\end{tabular}

Table III Jejunal $\left(\mathrm{Na}^{+}+\mathrm{K}^{+}\right)$ATPase activities in normal rats and following feeding sodium deoxycholate for three days ${ }^{1}$

${ }^{1}$ Expressed as $\mu \mathrm{g}$ of phosphate/mg protein/hour

JEJUNAL $\left(\mathrm{Na}^{+}+\mathrm{K}^{+}\right)$ATPase ACTIVITY (SEE TABLE III)

In control animals the $\left(\mathrm{Na}^{+}+\mathrm{K}^{+}\right)$ATPase activity of the mid-jejunum was $88 \pm 25 \mu \mathrm{g}$ phosphate per mg protein per hour. At the completion of the bile salt feeding period there was marked inhibition of $\left(\mathrm{Na}^{+}+\mathrm{K}^{+}\right)$ATPase activity $(17 \pm 8 ; \mathrm{P}<0.001)$. There was gradual recovery of enzyme activity over the following 72 hours to within normal limits.

HISTOCHEMICAL DEMONSTRATION OF ( $\mathrm{Na}^{+}+$ $\mathrm{K}^{+}$) A T Pase (fig 1)

In the intestines from normal controls, heavy deposits of reaction product were present on the brush border of enterocytes. At the end of the threeday bile salt feeding period a marked reduction in the histochemically demonstrable enzymatic activity on the luminal surface of the jejunal epithelium was observed. The loss of activity was not uniform and some enterocytes showed a greater reduction than others.

One day after the completion of the feeding period a slight increase in enzymatic activity occurred. During the ensuing two days the amount of reaction product gradually increased but was still less than in control tissues. Enterocytes in the basal regions of crypts displayed more enzymatic activity than surface cells.

By the end of the fourth day after the feeding period the appearances of experimental and control tissues were similar although a few cells still exhibited low enzymatic activity. These changes show a remarkable resemblance, in quantitative terms, to the rate of recovery of $\left(\mathrm{Na}^{+}+\mathrm{K}^{+}\right)$ATPase activity, as assessed chemically (see table III).

LIGHT AND ELECTRON MICROSCOPY (figs 2-7)

Light microscopy revealed no significant changes in 


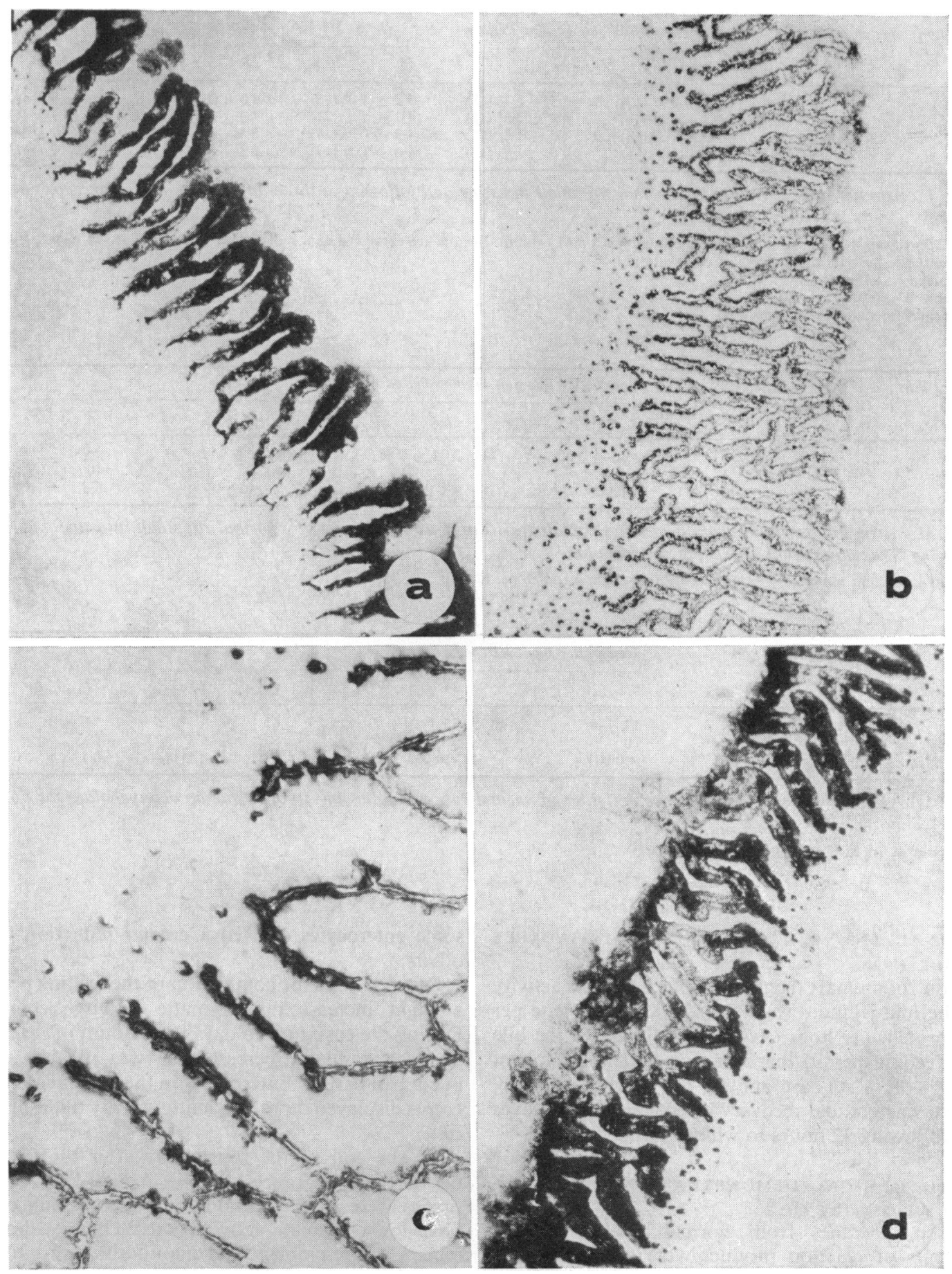

Fig 1 Histochemical demonstration of $\left(\mathrm{Na}^{+}+\mathrm{K}^{+}\right)$ATPase on rat intestine. (a) Normal control, $\times 35$. (b) After feeding deoxycholate for three days; $\times 40$ (c) After feeding deoxycholate for three days and then a normal diet for two days. Enterocytes lining the base of the crypts show more reaction product. $\times 140$. (d) After feeding deoxycholate for three days and then a normal diet for four days; recovery of enzymatic activity is almost complete. $\times 35$. 


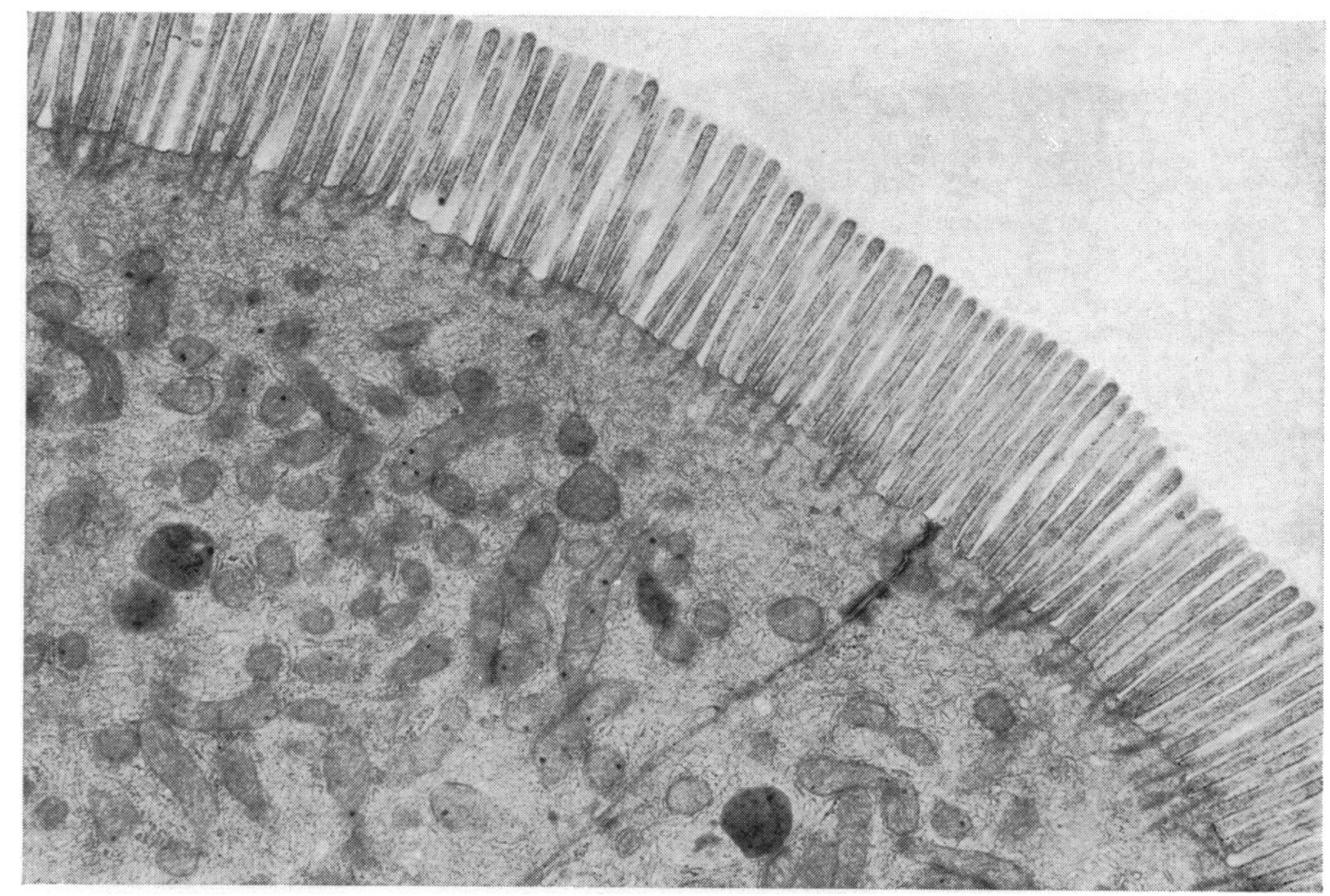

Fig 2 Normal rat intestine. Note regular, long slender microvilli. $\times 15000$.

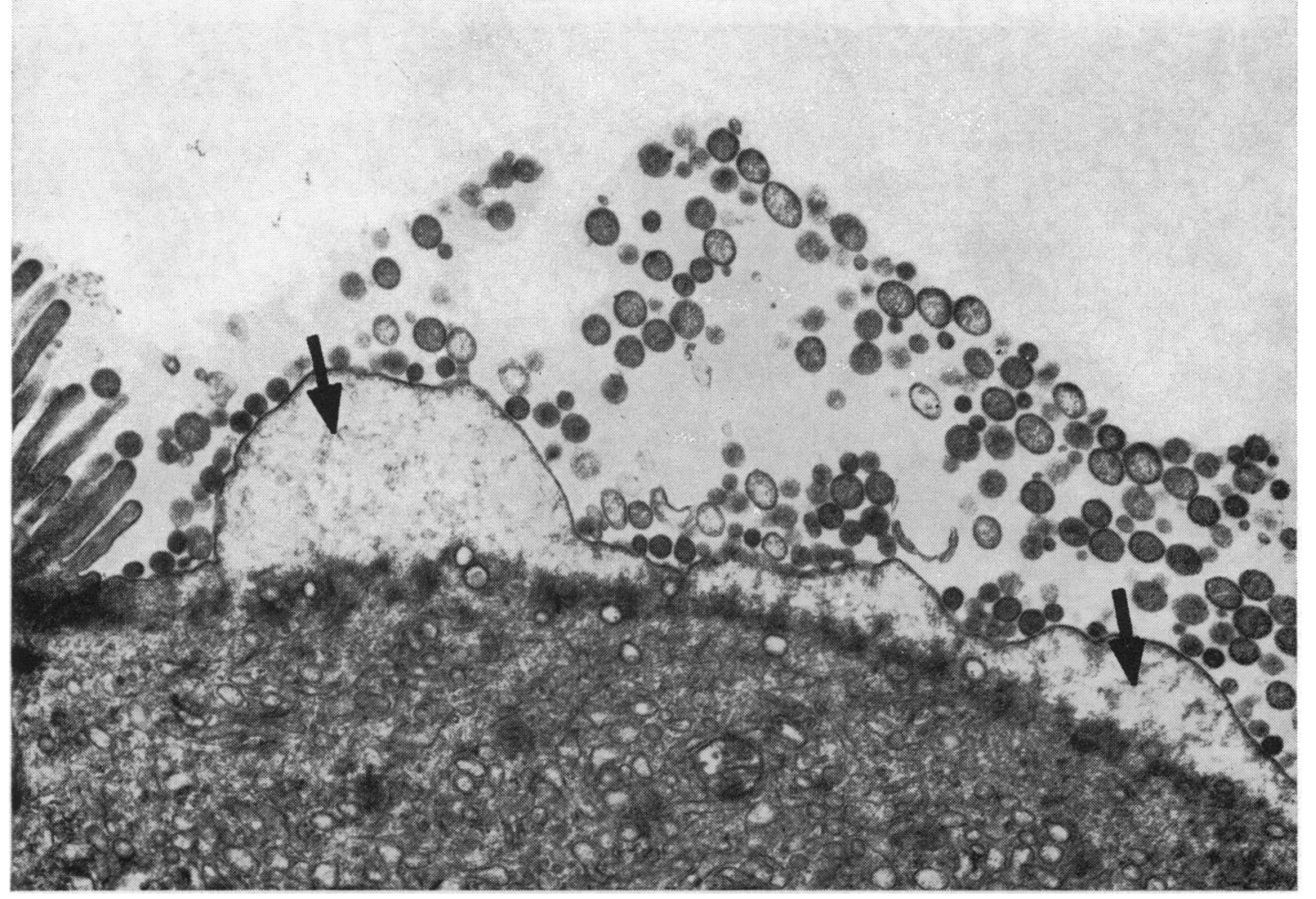

Fig 3 Enterocyte after feeding deoxycholate for three days. The surface shows prominent blebbing (arrows) and microvillar denudation. The remaining microvilli are swollen. $\times 19500$. 


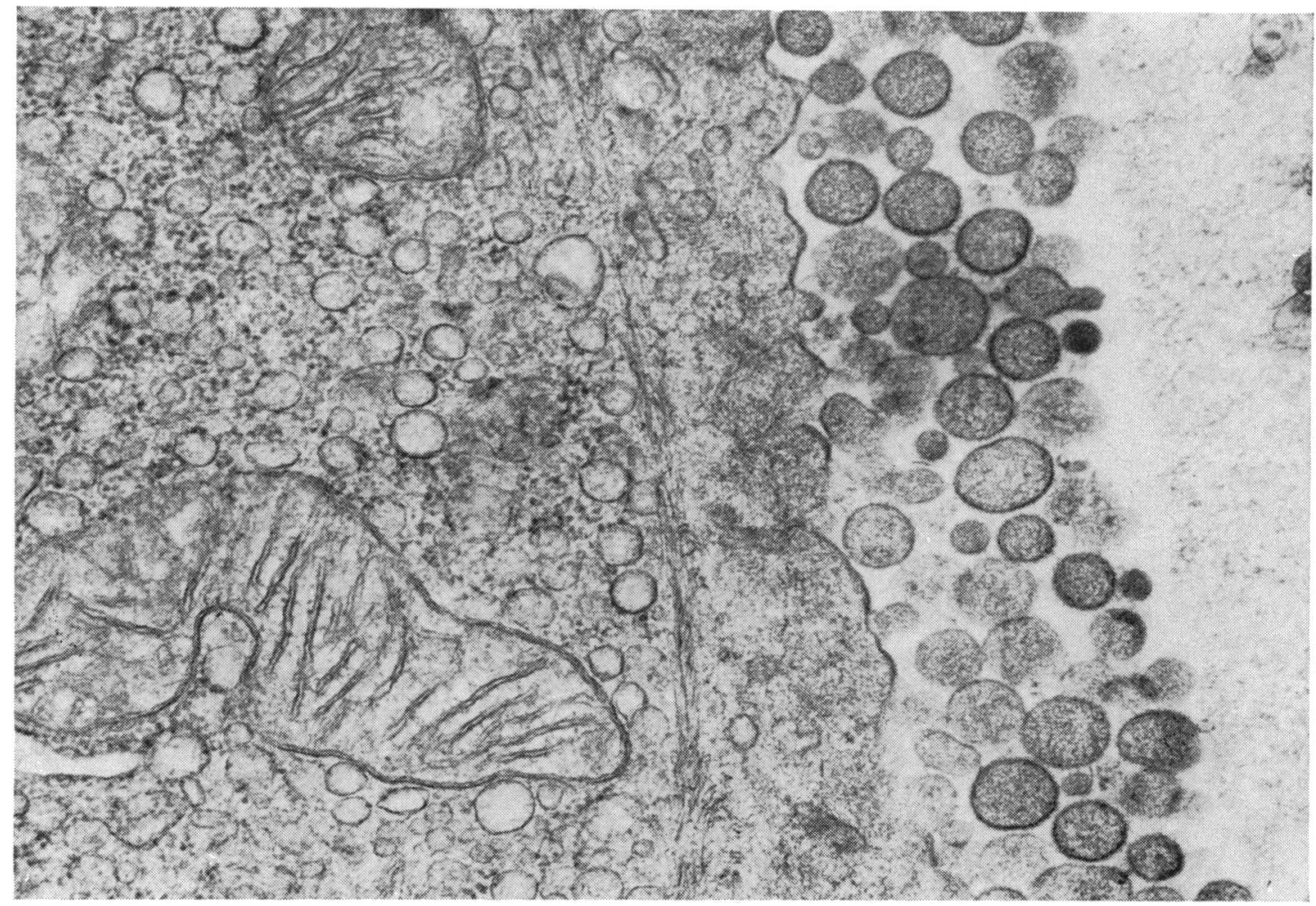

Fig 4 Enterocyte after feeding deoxycholate for three days. Microvilli are swollen and detached. The terminal web is disrupted, mitochondria are swollen, and endoplasmic reticulum is vesicular. $\times 35000$.

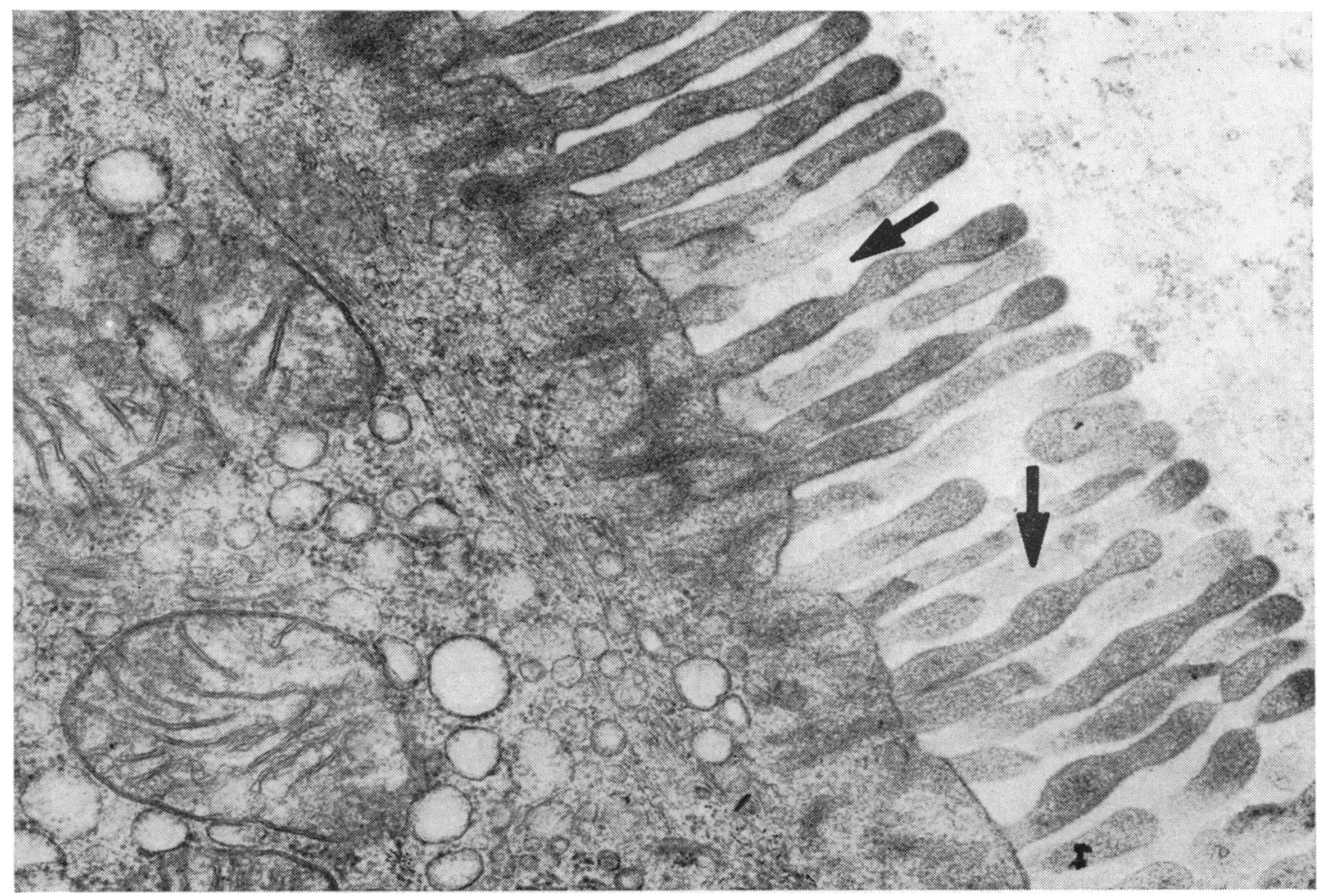

Fig 5 Enterocyte after feeding deoxycholate for three days. Some microvilli are irregular (arrows), mitochondria are swollen, and the ergastoplasm is vesicular. $\times 35000$. 




Fig 6 Enterocytes after feeding deoxycholate for three days. Some enterocytes show fewer and shorter microvilli while others show complete microvillar denudation (arrow) with disruption of the terminal web. Micropinocytosis is absent. $\times 29000$.

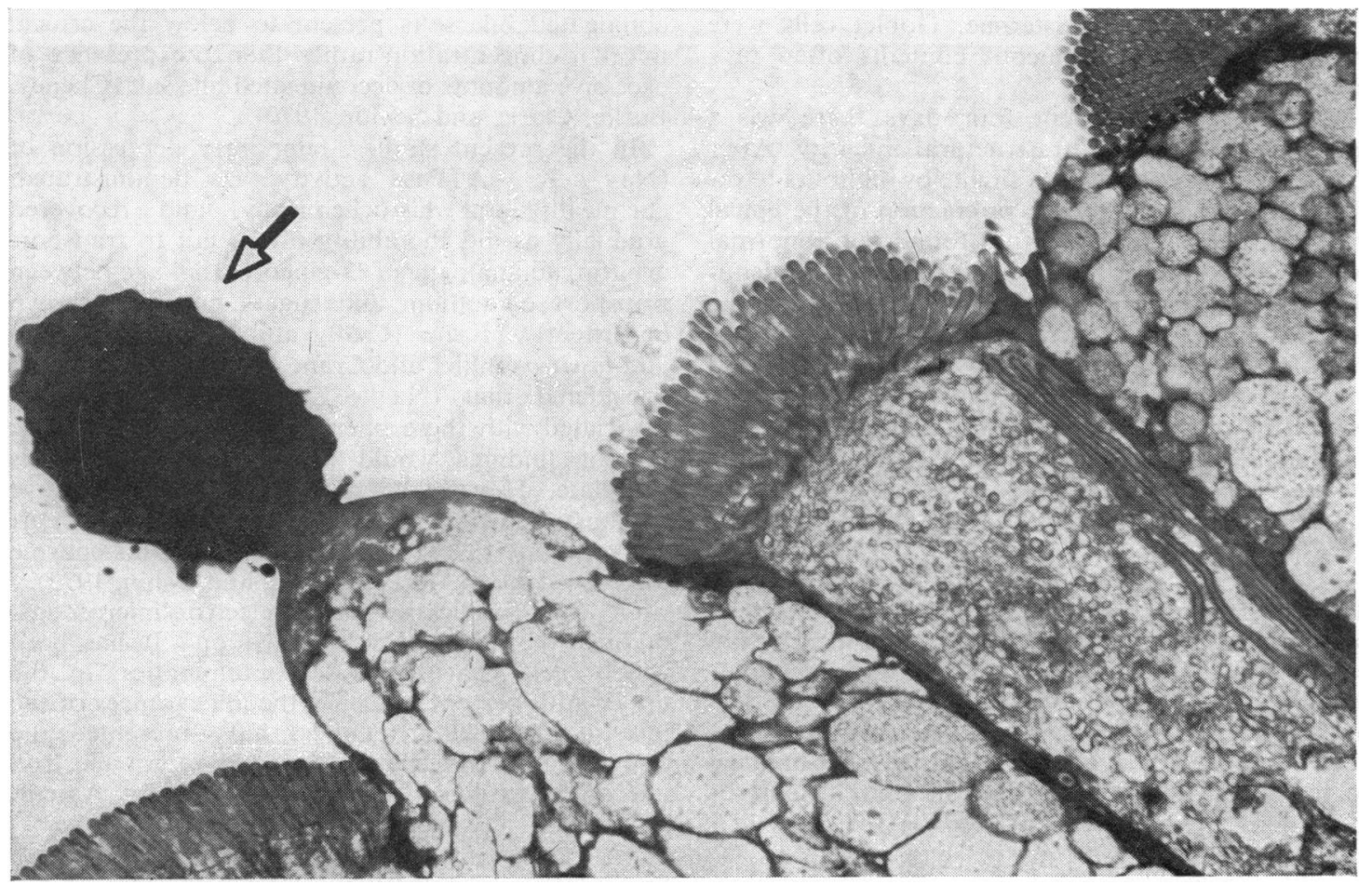

Fig 7 Enterocytes after feeding deoxycholate for three days and then with normal diet for another three days. The microvillar pattern is normal but the contents of goblet cells protrude into the lumen (arrow). $\times 11500$. 
the integrity of the small-intestinal epithelium after the end of the bile salt feeding period. The only detectable abnormality was a minor degree of separation of the submucosal tissues and components of the lamina propria.

However, at the end of the feeding period there were numerous enterocytic abnormalities when examined by electron microscopy. These structural lesions were more pronounced on the luminal surface of the epithelial cells but abnormalities were present in other parts of the enterocytic cytoplasm.

Some enterocytes were normal, while adjoining cells had shortened and blunted microvilli, often with a reduction in the concentration of microvilli; in some areas microvilli were virtually absent, presenting a flat, featureless contour.

Some microvilli were swollen and rounded, others were elliptical or fused together at their bases. The terminal web apparatus in these damaged cells was distorted and disorganized, often reduced in amount and sometimes almost completely absent. Micropinocytotic activity was reduced in these areas. In some cells the terminal web was replaced by a mass of scattered fibrils embedded in an electron-dense hyaloplasm. Cells with only few microvilli often showed rarefaction of the apical part of the cytoplasm which in addition lacked the normal concentration of organelles. The rest of the cytoplasm displayed various degrees of mitochondrial swelling, fragmentation of the rough endoplasmic reticulum, and degranulation of the cisternae. Goblet cells were prominent and their mucous contents often protruded into the lumen.

During the subsequent four days there was a gradual recovery of ultrastructural integrity. After 24 hours improvement was slight; by 48 hours fewer damaged cells were visible, rarefaction of the apical part of the cytoplasm was not found but abnormal microvilli and enterocytes with microvillar denudation were still seen in a few cells. By the end of the fourth day very few damaged cells were found but occasional enterocytes with all the described changes, except rarefaction of the apical cytoplasm, were still present. Large mucus-containing goblet cells remained prominent.

\section{Discussion}

The present study indicates that important, deleterious effects on small-intestinal function and structure can be induced experimentally by feeding a deconjugated bile salt orally. In these experiments there was impairment of intestinal active sugar transport and $\left(\mathrm{Na}^{+}+\mathrm{K}^{+}\right)$ATPase activity while extensive damage to the microvillar and cytoplasmic parts of entero- cytes was evident by electron microscopy. All these changes recovered significantly within four days of returning the animals to a normal diet. The experimental model used is a convenient one and could be used to examine further the interrelationships of bile salt metabolism and intestinal sugar transport.

Malabsorption of carbohydrate occurs in patients with bacterial contamination of the upper gut (Paulk and Farrar, 1964; Donaldson, 1967), particularly infants (Gracey, Burke, and Anderson, 1969), presumably because of the presence of excessive amounts of deconjugated bile salts (Gracey et al, 1971c) produced in the lumen of the gut by bacterial degradation. This suggested mechanism seems supported by recent experiments in which impaired intestinal sugar transport was produced in rats in vivo by surgically inducing stasis and bacterial overgrowth in the upper gut (Gracey et al, 1971c) or by perfusing the intact normal upper gut with solutions containing deconjugated bile salts (Gracey, Burke, and Oshin, 1971b; Harries and Sladen, 1972). The effect appears to be a direct inhibition of the intestinal active sugar transport pathway by these substances since it is not modified by the presence of normal amounts of conjugated bile salt (Gracey et al, 1971b). In this way, it differs from the pathogenesis of steatorrhoea in the "contaminated small-bowel syndrome' where the most important factor is reduction of the amount of conjugated bile salts present to below the critical micellar concentration rather than the presence of excessive amounts of deconjugated bile salt (Cheney, Burke, Clark, and Senior, 1970).

In the present studies, temporary depression of $\left(\mathrm{Na}^{+}+\mathrm{K}^{+}\right)$ATPase activity was demonstrated, chemically and histochemically, and recovered gradually as did the ability of the gut to transport arbutin, an analogue of D-glucose. Linkage between transport of sodium and sugars has been shown consistently in vivo (Csáky and Zollicoffer, 1960) and in vitro (Bihler and Crane, 1962), and it is often considered that $\left(\mathrm{Na}^{+}+\mathrm{K}^{+}\right)$ATPase is closely associated with these phenomena (Skou, 1965). The present findings would appear to support this postulate. However, recent studies in vitro have demonstrated that intestinal active sugar transport can continue in the virtual absence of this enzyme activity (Gracey, Burke, Storrie, and Oshin, 1972).

Of what significance are the electron microscopic findings of the present investigation? It has been widely held that bacterial contamination in the upper gut does not influence the appearances of the intestinal epithelium. Others have presented the opposite view (Paulley, 1969) and recent electron microscopy studies (Gracey et al, 1971c; Ament, 
Shimoda, Saunders, and Rubin, 1972) have shown extensive damage to enterocytes in patients and experimental animals with an abnormal small intestinal flora. Morphological changes have also been induced experimentally by using deconjugated bile salts. Fry and Staffeldt (1964) added $2 \%$ sodium deoxycholate to the diet of mice and subsequently observed submucosal oedema and separation in the duodenum with some later denudation of ileal enterocytes; these changes were temporary and attributed to the surface action of the bile salt on the cells. Shiner (1969) instilled deoxycholate intraduodenally in rats and, by adjusting the concentration of the bile salt, was able to induce significant ultrastructural changes while the appearance of the epithelium on light microscopy was normal. In the present study the integrity of the intestinal epithelium was maintained to light microscopic appearances yet there was extensive and irregularly distributed damage to the epithelial cells evident on electron microscopy. The interpretation of the significance of these findings is difficult. They show close similarities to those found in experimental animals in which deoxycholate is instilled intraduodenally (Shiner, 1969) and in rats with a self-filling jejunal blind loop (Gracey et al, 1971c). They are therefore, probably, of more relevance than the more marked histological findings reported previously in experiments conducted in vitro with deoxycholate or by perfusing the deconjugated bile salt into isolated loops of gut in vivo (Low-Beer, Schneider, and Dobbins, 1970; Tomkin and Love, 1972). These latter experiments involve a considerable amount of inevitable experimental interference under somewhat unphysiological conditions. Apart from these criticisms, the present method may have more relevance than acute experiments, such as those mentioned above, to clinical situations in which deconjugated bile salts affect small intestinal function over days, weeks, or months, rather than for minutes or a couple of hours as in acute experiments. Furthermore, it is much more convenient than another alternative technique in which prolonged bacterial contamination and deconjugation of bile salts are produced surgically by the construction of a self-filling jejunal blind loop (Cameron, Watson, and Witts, 1949).

The technique used in these experiments appears to be a convenient and acceptable one in which the interrelationships of bile salts and intestinal sugar transport can be pursued further. It results in temporary impairment of sugar transport and $\left(\mathrm{Na}^{+}+\right.$ $\mathrm{K}^{+}$) ATPase activity as well as ultrastructural damage to the small-intestinal epithelium. These abnormalities return towards normal within a few days, probably because of regeneration of the epithelial cells (Leblond and Stevens, 1948).
We thank Mrs A. Malajczuk for her technical assistance.

\section{References}

Alvarado, F., and Crane, R. K. (1964). Studies on the mechanism of intestinal absorption of sugars. VII. Phenylglycoside transport and its possible relationship to phlorizin inhibition of the active transport of sugars by the small intestine. Biochim. biophys. Acta (Amst.), 93, 116-135.

Ament, M. E., Shimoda, S. S., Saunders, D. R., and Rubin, C. E. (1972). The pathogenesis of steatorrhea in three cases of small intestinal stasis syndrome. Gastroenterology, 63, 728-747.

Bihler, I., and Crane, R. K. (1962). Studies on the mechanism of intestinal absorption of sugars. $V$. The influence of several cations and anions on the active transport of sugars in vitro, by various preparations of hamster intestine. Biochim. biophys. Acta (Amst.), 59, 78-93.

Cameron, D. G., Watson, G. M., and Witts, L. J. (1949). The experimental production of macrocytic anemia by operations on the intestinal tract. Blood, 4, 803-815.

Cheney, F. E., Burke, V., Clark, M. L., and Senior, J. R. (1970). Intestinal fatty acid absorption and esterification from luminal micellar solutions containing deoxycholic acid. Proc. Soc. exp. Biol. (N.Y.), 133, 212-215.

Crane, R. K., and Mandelstam, P. (1960). The active transport of sugars by various preparations of hamster intestine. Biochim. biophys. Acta (Amst.), 45, 460-476.

Csàky, T. Z., and Zollicoffer, L. (1960). Ionic effect on intestinal transfer of glucose in the rat. Amer. J. Physiol., 198, 1056-1058.

Donaldson, R. M., Jr. (1967). Role of enteric microorganisms in malabsorption. Fed. Proc., 26, 1426-1431.

Ernst, S. A. (1972). Transport adenosine triphosphatase cytochemistry. II. Cytochemical localization of ouabain-sensitive, potassiumdependent phosphatase activity in the secretory epithelium of the avian salt gland. J. Histochem. Cytochem., 20, 23-38.

Folin, O., and Ciocalteu, V. (1927). On tyrosine and tryptophane determination in proteins. J. biol. Chem., 73, 627-650.

Fry, R. J. M., and Staffeldt, E. (1964). Effect of a diet containing sodium deoxycholate on the intestinal mucosa of the mouse. Nature (Lond.), 203, 1396-1398.

Gracey, M., Burke, V., and Anderson, C. M. (1969). Association of monosaccharide malabsorption with abnormal small-intestinal flora. Lancet, 2, 384-385.

Gracey, M., Burke, V., and Oshin, A. (1971a). Reversible inhibition of intestinal active sugar transport by deconjugated bile salt in vitro. Biochim. biophys. Acta (Amst.), 225, 308-314.

Gracey, M., Burke, V., and Oshin, A. (1971b). Influence of bile salts on intestinal sugar transport in vivo. Scand. J. Gastroent., 6, 273-276.

Gracey, M., Burke, V., Oshin, A., Barker, J., and Glasgow, E. F. (1971). Bacteria, bile salts, and intestinal monosaccharide malabsorption. Gut, 12, 683-692.

Gracey, M., Burke, V., Storrie, M., and Oshin, A. (1972). Dissociation of intestinal active sugar transport from $\left(\mathrm{Na}^{+}+\mathrm{K}^{+}\right)$ATPase activity. Clin. chim. Acta (Amst.), 36, 555-560.

Harries, J. T., and Sladen, G. E. (1972). The effects of different bile salts on the absorption of fluid, electrolytes, and monosaccharides in the small intestine of the rat in vivo. Gut, 13, 596-603.

Hirschorn, N., and Rosenberg, I. H. (1968). Sodium-potassium stimulated adenosine triphosphatase of the small intestine of man: studies in cholera and other diarrheal diseases. J. Lab. clin. Med., 72, 28-39.

Hydén, S. (1956). A turbidometric method for the determination of higher polythene glycols in biological materials. LantbrHögsk, Annlr., 22, 139-145.

Krebs, H. A., and Henseleit, K. (1932). Untersuchungen uber die Harnstoffbildung im Tierkörper. Hoppe-Seylers Z. physiol. Chem., 210, 33-36.

Leblond, C. P., and Stevens, C. E. (1948). The constant renewal of the intestinal epithelium in the albino rat. Anat. Rec. (Lond.), 100, 357-377.

Low-Beer, T. S., Schneider, R. E., and Dobbins, W. O. (1970). Morphological changes of the small-intestinal mucosa of guinea pig and hamster following incubation in vitro and perfusion in vivo with unconjugated bile salts. Gut, 11, 486-492. 
Lowry, O. H., Rosebrough, N. J., Farr, A. L., and Randall, R. J. (1951). Protein measurement with the Folin phenol reagent. J. biol. Chem., 193, 265-275.

Paulk, E. A., Jr., and Farrar, W. E., Jr. (1964). Diverticulosis of the small intestine and megaloblastic anemia. Amer. J. Med., 37, 473-480.

Paulley, J. W. (1969). The jejunal mucosa in malabsorptive states with high bacterial counts. In Malabsorption, edited by $\mathbf{R}$. $\mathbf{H}$. Girdwood and A. N. Smith, pp. 171-181. University of Edinburgh Press, Edinburgh.

Semenza, G., and Mulhaupt, E. (1969). Studies on intestinal sucrase and sugar transport. VII. A method for measuring intestinal uptake. The absorption of the anomeric forms of some monosaccharides. Biochim. Biophys. Acta (Amst.), 173, 104-112.
Shiner, M. (1969). Effect of bile acids on the small intestinal mucosa in man and rats: a light and electron microscopic study. In Bile Salt Metabolism, edited by L. Schiff, J. B. Carey, and J. Dietschy (Conference, Cincinatti, 1967), pp. 41-45. Thomas, Springfield, Illinois.

Skou, J. C. (1965). Enzymatic basis for active transport of $\mathrm{Na}^{+}$and $\mathrm{K}^{+}$ across cell membrane. Physiol. Rev., 45, 596-617.

Tomkin, G. H., and Love, A. H. G. (1972). Investigation of glucose transport and ${ }^{57}$ Co Vitamin $B_{18}$ uptake using the everted sac technique with histological examination of the sacs after suspension in bile salts and indole. Digestion, 6, 129-138.

Waravdekar, V. S., and Saslaw, L. D. (1957). A method of estimation of 2-deoxyribose. Biochim. Biophys. Acta (Amst.), 24, 439. 